\title{
Antithrombin III in patients on long-term oral anticoagulants
}

\author{
H BULL,* I MACKIE, $\dagger$ M BROZOVIĆ, AND D WOODINGS \\ From the Department of Haematology, Central Middlesex Hospital, London NW10, UK
}

SUMMARY The antithrombin III (AT III) concentration in plasma was measured in 63 patients on oral anticoagulant treatment (mean age 57.7 years), 26 healthy laboratory controls (mean age 28 years), and 21 patients attending the hypertensive clinic who had never been on oral anticoagulants (mean age 50 years). Three methods were used to measure AT III : a coagulation assay, a chromogenic substrate assay, and an immunological assay. In patients on oral anticoagulants, the mean values for AT III in the three assays were: $124 \%, 107 \%$, and $96 \%$ respectively. The mean AT III concentration in laboratory staff was $103.4 \%, 94 \%$, and $104.1 \%$ for the three assays; patients attending the hypertensive clinic had AT III concentrations indistinguishable from those in patients on oral anticoagulants: $117.9 \%, 110.5 \%$, and $93.9 \%$. The difference between both patient groups and laboratory staff was statistically highly significant, but no difference was demonstrated between patients on anticoagulant treatment and those not receiving it. Our results show that the increase in the functional AT III concentration (measured by coagulation and chromogenic assays) observed in patients on oral anticoagulants is probably due to the effects of age and underlying disease rather than to the anticoagulant treatment itself.

Decreased plasma levels of AT III are associated with an increased incidence of thromboembolic disease, as seen in congenital deficiency, in women taking oral contraceptives with high oestrogen content, and during the postoperative period (for recent review see Barrowcliffe et al. ${ }^{1}$ and Davies and $\mathrm{McNicol}^{2}$ ).

Marciniak et al. ${ }^{3}$ reported an increase in plasma AT III concentration in congenitally deficient individuals when they were given small doses of oral anticoagulants. O'Brien and Etherington ${ }^{4}$ found that patients on long-term oral anticoagulant therapy for thromboembolic conditions had higher AT III plasma concentrations than healthy controls.

In contrast, Wessler et al..$^{5}$ reported that plasma AT III was similar in patients on oral anticoagulants and controls, but that the Xa inhibitory activity was significantly higher in those on warfarin. To establish whether or not the AT III concentration rises in patients on oral anticoagulants we have investigated

*Supported by locally organised research scheme, North West Thames Regional Health Authority

†British Heart Foundation Research Fellow

Received for publication 10 April 1980
63 patients on long-term oral anticoagulants ando compared the values obtained with those of two? control groups: healthy laboratory staff and hospital patients not on oral anticoagulants. If an increase in plasma AT III concentration occurs regularly with the administration of oral anticoagulants, an entirely different dose schedule and pattern of administration may be effective and justifiable in the prophylaxis of deep venous thrombosis.

\section{Methods and subjects}

CONTROLS

Two control groups were studied. The first group consisted of 13 men and 13 women. They were members of the laboratory staff and their mean age was 28 years (Table 1). Five women were taking low oestrogen contraceptive pills; their AT III values did not differ from those in the women not taking the pill and they were included in the control group. The second control group comprised 21 patients attending the hypertensive clinic. There were 12 men and nine women and their mean age was 50 years. These patients received a variety of antihypertensive drugs, including $\beta$ blockers, hydrallazine, methyl dopa, and diuretics, but they had never taken oral anticoagulants. 
Table 1 Details of subjects studied

\begin{tabular}{|c|c|c|c|c|c|c|}
\hline \multirow[t]{2}{*}{ Group } & \multicolumn{2}{|c|}{ Men } & \multicolumn{2}{|c|}{ Women } & \multicolumn{2}{|c|}{ Total } \\
\hline & No. & $\begin{array}{l}\text { Age, } \\
\text { mean }\end{array}$ & No. & $\begin{array}{l}\text { Age, } \\
\text { mean }\end{array}$ & No. & $\begin{array}{l}\text { Age, } \\
\text { mean }\end{array}$ \\
\hline $\begin{array}{l}\text { Laboratory staff } \\
\text { Patients not on }\end{array}$ & 13 & 28 & 13 & 29 & 26 & 28 \\
\hline $\begin{array}{l}\text { oral anticoagulants } \\
\text { Patients on oral } \\
\text { anticoagulants: }\end{array}$ & 12 & 53 & 9 & 46 & 21 & 50 \\
\hline $\begin{array}{l}\text { Group } 1 \\
\text { Group } 2 \\
\text { Group } 3\end{array}$ & $\begin{array}{r}15 \\
11 \\
7\end{array}$ & $\begin{array}{l}55 \\
62 \\
60\end{array}$ & $\begin{array}{l}15 \\
15 \\
-\end{array}$ & $\begin{array}{l}58 \\
58 \\
-\end{array}$ & $\begin{array}{r}30 \\
26 \\
7\end{array}$ & $\begin{array}{l}56 \\
59 \\
60\end{array}$ \\
\hline
\end{tabular}

\section{PATIENTS}

A total of 63 patients stabilised on oral anticoagulants were studied. The patients had been on warfarin for at least three months since the last thromboembolic episode. They comprised three groups of individuals: group 1-30 patients who had had deep venous thrombosis and/or pulmonary embolism; group 2-26 patients with mitral valve disease; and group 3-seven men who had been anticoagulated after myocardial infarction. The details of age and sex are shown in Table 1.

\section{METHODS}

AT III concentration was measured using three techniques:

1 Progressive antithrombin activity (PAT) by the coagulation assay of Abildgaard et al. ${ }^{6}$ Bovine fibrinogen (Diagnostic Reagents Ltd, Thame, Oxon) was used as substrate and Parke Davis bovine thrombin as enzyme.

2 Amidolytic assay of AT III (Chrom AT III) with the chromogenic substrate S 2238 (a generous gift of Kabi-Vitrum Ltd) using Fibrindex, human thrombin (Ortho Diagnostics Ltd, High Wycombe, Bucks), according to the method of Odegaard et al. ${ }^{7}$

3 AT III antigen (AT III Ag) was determined by rocket immunoelectrophoresis ${ }^{8}$ using Behringwerke antiserum (Hoechst UK Ltd, Hounslow).

Blood samples were collected into $3 \cdot 13 \%$ citrate, and the plasmas were separated and stored for up to two weeks at $-20^{\circ} \mathrm{C}$ before being assayed in batches. Pooled fresh normal plasma (10 donors) was assigned $100 \%$ potency and was used as a standard in PAT and AT III Ag assays. The standard for the Chrom AT III was the freeze-dried normal plasma supplied by Kabi Vitrum Ltd.

Thrombotest was performed on citrated venous blood according to the method recommended by Nyegaard and Co. A/S Oslo. The results were analysed using Student's $t$ test and the linear coefficient of correlation.

\section{Results}

The results obtained with the PAT assay are shown in Figure 1. The mean values were $103.4 \%$ for laboratory controls, $\mathbf{1 1 7 . 9} \%$ for patients not on oral anticoagulants, $130.2 \%$ for group 1 anticoagulated patients, $117.7 \%$ for group 2 , and $117.1 \%$ for group 3. The PAT values were significantly higher in hypertensive patients and in groups 1 and 2 than in the laboratory controls. Group 3 was too small for analysis.

AT III levels measured by the chromogenic assay are shown in Figure 2. Again laboratory controls showed lower values than the patients, and there was no difference between different patient groups. Mean Chrom AT III values were $94.2 \%$ for laboratory controls, $110.5 \%$ for hypertensive patients, $106.5 \%$ for group 1 patients on anticoagulants, $105.6 \%$ for group 2 , and $111.5 \%$ for group 3 .

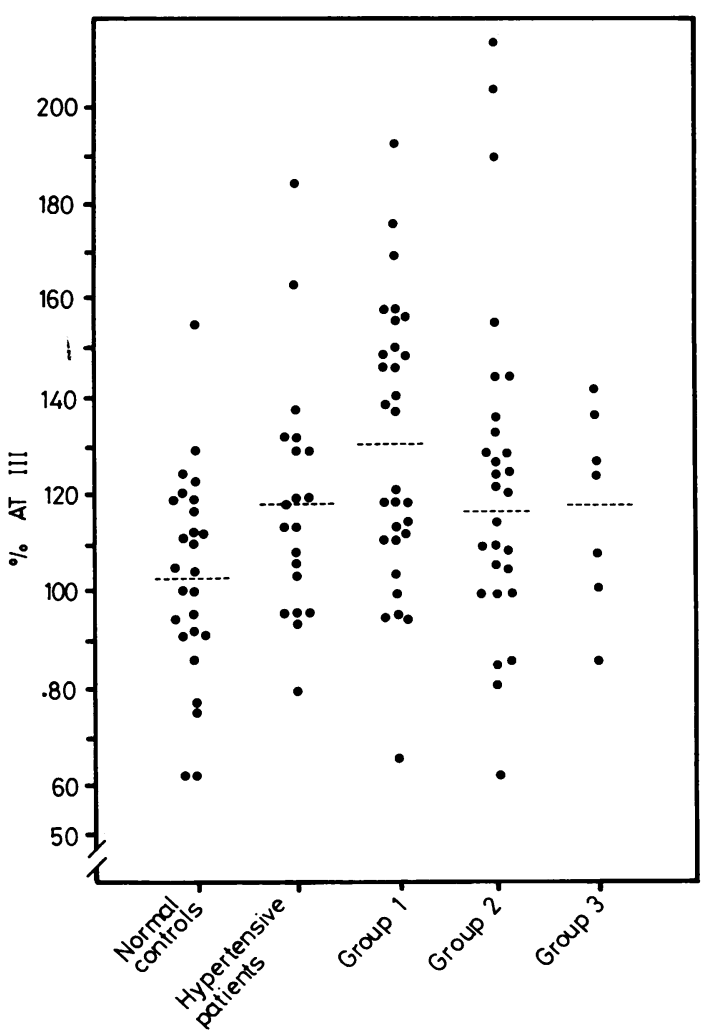

Fig. 1 AT III levels measured using PAT assay in laboratory controls, hypertensive patients, and patients on oral anticoagulants. Each dot represents one measurement in one patient; the dotted line denotes the mean for each group. 


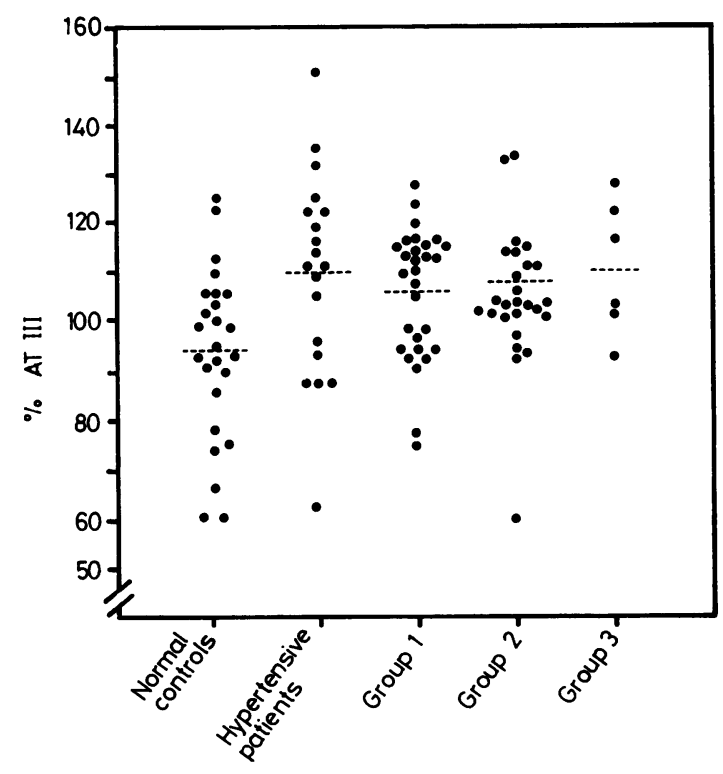

Fig. 2 AT III levels measured using chromogenic assay. For explanation see Fig. 1.

The results of the immunological assay are shown in Figure 3. Laboratory controls had higher mean AT III antigen (104.1\%) than hypertensive patients $(93.9 \%)$, anticoagulated patients group $1(98.6 \%)$, group $2(96.2 \%)$, and group $3(90 \cdot 2 \%)$. These differences were significant (Table 2). There was no correlation between Thrombotest values and any of the AT III modalities measured.

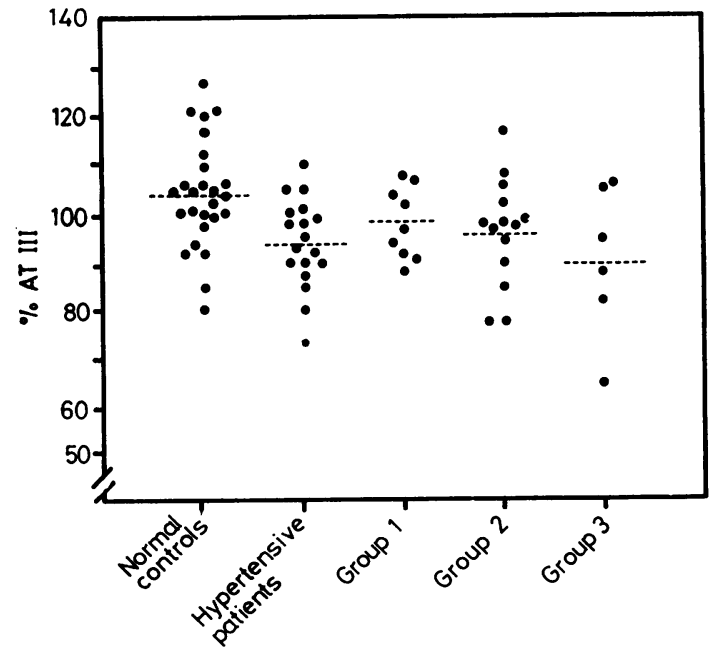

Fig. 3 AT III levels measured using immunoassay. For explanation see Fig. 1.
Table 2 Statistical analysis of AT III measurement obtained with three assays

\begin{tabular}{|c|c|c|c|}
\hline & $P A T$ & Chrom AT III & $A T I I I A g$ \\
\hline $\begin{array}{l}\text { Laboratory controls } \\
v \text { hypertensive patients } \\
v \text { group } 1 \\
v \text { group } 2 \\
v \text { all anticoagulated } \\
\text { patients } \\
\text { Hypertensive patients } \\
v \text { group } 1 \\
v \text { group } 2 \\
v \text { all anticoagulated } \\
\text { patients }\end{array}$ & $\begin{array}{l}<0.02 \\
<0.001 \\
\text { ns } \\
<0.005 \\
\text { ns } \\
<0.025 \\
\text { ns }\end{array}$ & $\begin{array}{l}<0.025 \\
<0.01 \\
<0.02 \\
<0.1 \\
\text { ns } \\
\text { ns } \\
\text { ns }\end{array}$ & $\begin{array}{l}<0.02 \\
<0.05 \\
<0.05 \\
<0.01\end{array}$ \\
\hline
\end{tabular}

We have also followed the AT III concentration, using the chromogenic assay, in three patients starting anticoagulant treatment (Fig. 4). Case 1 received oral anticoagulants only and his AT III levels remained higher than normal throughout the period of observation. Cases 2 and 3 were given heparin and warfarin during the first three days of therapy, and warfarin alone thereafter. Their AT III levels on the first day of treatment were lower than in Case 1. The AT III concentration showed a slight rise when heparin was discontinued.

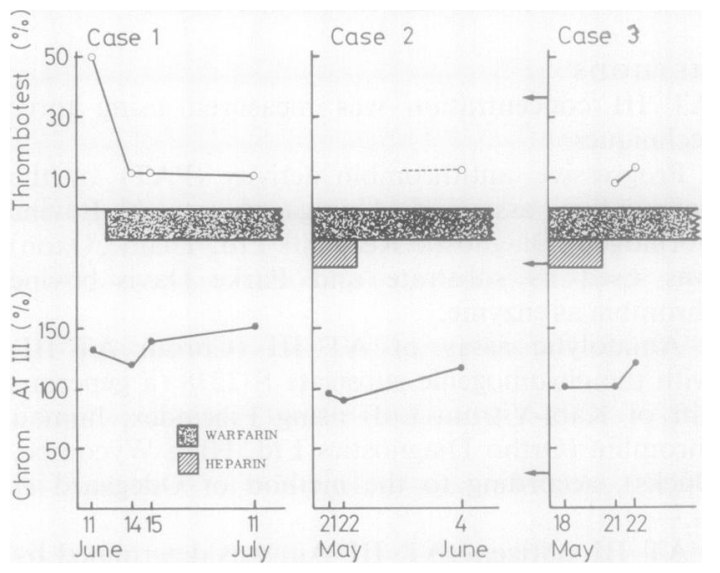

Fig. 4 AT III levels and Thrombotest values in three patients starting therapy. For details see text.

\section{Discussion}

In comparison with healthy young controls, our patients on oral anticoagulants had higher mean PAT and Chrom AT III levels and lower AT III Ag concentrations. Surprisingly, similar high PAT and Chrom AT III values and low AT III Ag were obtained in a group of hypertensive patients not on oral anticoagulants. This suggests that the changes observed are due to the effects of age and/or disease rather than to warfarin therapy. 
Meade and North $^{9}$ reported that AT III Ag decreases with age, but no changes in AT III functional activity were observed in the industrial population studied. Increased levels of functional AT III have been described in ischaemic heart disease, ${ }^{10}$ after myocardial infarction, ${ }^{11}$ and as part of acute phase reaction. ${ }^{1}$ Our results emphasise the need for careful selection of controls for AT III assays.

Direct comparison of AT III values was possible only for PAT and AT III Ag assay where the same standard was used throughout. The two values were in good agreement in laboratory controls but showed a marked discrepancy in all patient groups where high PAT values were often associated with low AT III Ag values.

Poor correlation between functional and immunological AT III is well recognised 12 and thought to be an index of AT III consumption. The discrepancy may also arise as a result of endothelial damage and disease, as Chan and $\mathrm{Chan}^{13}$ have recently demonstrated that AT III is present in the endothelial cells.

A fall in plasma AT III levels during heparin therapy is well documented, as is the subsequent rise while patients are given oral anticoagulants alone. $^{314}$ Our observations on three patients confirm these findings and may explain the rise in AT III level seen during the early stages of anticoagulant therapy; this may well be the return to high pretreatment values after the heparin-induced fall. A larger series of patients tested regularly before, during, and after heparin and warfarin treatment is required to clarify this problem.

\section{References}

${ }^{1}$ Barrowcliffe TWA, Johnson EA, Thomas D. Antithrombin
III and heparin. Br Med Bull 1978;34:143-50.

2 Davies JA, McNicol GP. Blood coagulation and thrombosis. Br Med Bull 1978;34:113-20.

${ }^{3}$ Marciniak E, Farley CH, Desimone PA. Familial thrombosis due to antithrombin III deficiency. Blood 1974;43: 1219-31.

4 O'Brien J, Etherington MD. The effect of heparin and warfarin on antithrombin III. (Letter.) Lancet 1977 ;ii: 1232.

${ }^{5}$ Wessler S, Gitel SN, Bank H, Martinowitz U, Stephenson RC. An assay of the antithrombotic action of warfarin: its correlation with the inhibition of stasis thrombosis in rabbits. Thromb Haemostas 1978;40:486-98.

- Abildgaard U, Graven K, Godal HC. Assay of progressive antithrombin in plasma. Thromb Diath Haem 1970;24: 224-9.

? Odegaard OR, Lie M, Abildgaard U. Heparin cofactor activity measured with an amidolytic method. Thromb Res $1975 ; 6: 287-94$.

8 Laurell CB. Quantitative estimation of proteins by electrophoresis in agarose gel containing antibodies. Anal Biochem 1966;15:45-69.

- Meade TW, North WRS. Population based distributions of haemostatic variables. Br Med Bull 1977;33:283-8.

10 Yue RH, Gertler MM, Starr T, Kontronby R. Alteration of plasma antithrombin III levels in ischaemic heart disease. Thromb Haemostas 1976;35:598-607.

11 Pratt HW. Alterations in plasma antithrombin III activity in patients with myocardial infarction. Proc III Congr ISTH, Washington 1972;79.

12 Phillip JAD, Walker ID, Davidson JF. The ratio of functional:immunologic antithrombin III as an index of antithrombin consumption. Proc VII Int Congr Thromb Haem, London 1979;375.

${ }^{13}$ Chan TK, Chan V. The effect of venous occlusion on antithrombin III, plasminogen activator and fibrinogen degradation product (fragment E) levels. Thromb Res 1979;14:525-34.

14 Marciniak E, Gockerman JP. Heparin induced decrease in circulating antithrombin III. Lancet 1977; ii:581-4.

Requests for reprints to: Dr M Brozovic, Haematology Department, Central Middlesex Hospital, Acton Lane, London NW10 7NS. 